\title{
Teaching US Politics in the Age of Trump: International Perspectives
}

\section{INTRODUCTION TO TEACHING US POLITICS IN THE AGE OF TRUMP: INTERNATIONAL PERSPECTIVES}

Claudia Franziska Brühwiler, University of St. Gallen, Switzerland Hiroshi Okayama, Keio University, Japan

DOI: $10.1017 / S_{1049096519002014}$

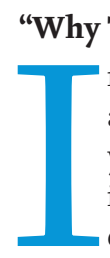
Trump?" equally concerned about the causes and effects of party polarization, the "costs" of American democracy, and the influence of the media and lobbies. Although these questions are still at the center of many discussions, a resounding "why?" pervades the classroom whenever the Trump administration is mentioned. They ask, "Why could someone who has never held any public office and lacks a strong tie to any political party still be elected to the nation's highest office while speaking and acting so divisively, and how has that impacted the American democracy?" At the end of the semester, students report that although they better understand how the US system works and why it now may favor polarizing candidates, they are not fully convinced that it can be effectively shielded from democratic erosion. Referencing Federalist Paper No. 51, students recognize that the system was designed to withstand the grasp of not particularly angelic executives; however, intention and reality may diverge.

Students are not alone in having difficulty in making sense of and deciding how to react to the Trump administration, as the ongoing discussions among political scientists convey. In addition to asking "why," scholars are discussing the effects of the Trump presidency on the classroom. Panels at annual meetings of the American Political Science Association have explored ways to increase students' readiness to become politically active, and a symposium in New Political Science analyzed transformative practices (Romano and Daum 2018). Debates in The Chronicle of Higher Education and online forums suggest a heightened awareness for questions of teacher neutrality and the role of emotions and for the challenges in educating critical readers who can maneuver the world of online (mis)information.

However, these discussions tend to focus on the US context, overlooking the fact that American politics is taught around the world, in countries whose historic relations with the United States shape public-and classroom-debates as much as current politics. That is, we automatically adopt a comparative perspective when we discuss US politics in international classrooms, and we tend to continuously question the effects of US politics and policy on the international realm-specifically, our own geopolitical context. Contrary to what happens when US students examine their own political system from a comparative perspective (Baron, Blair, and Grossman 2019), our discussions may end less than optimistically. (Or they may be regarded as futile in the first place: an exchange student from Hong Kong once told one of the guest editors of this spotlight that he had been wondering the entire semester why his fellow students had such heated debates on political ideas; why care about ideas if individual citizens have such little impact?)

This spotlight invites readers to what is intended to be a more international conversation on the challenges of teaching US politics, in general, and particularly considering the standing of the current administration. The conversation takes us to campuses in Europe (i.e., Germany and the United Kingdom), in two Asian countries with a historically ambiguous relationship to the United States (i.e., South Korea and Japan), and in Australia and the Middle East (i.e., Lebanon).

\section{REFERENCES \\ Baron, Hannah, Robert A. Blair, and Shelby Grossman. 2019. "Teaching Trump: Why Comparative Politics Makes Students More Optimistic about US Democracy." PS: Political Science \& Politics 52 (2): 347-52. \\ Romano, Sarah T., and Courtenay W. Daum. 2018. "Symposium: Transformative Practices of Teacher-Scholar-Activists in the Era of Trump." New Political Science $40(3): 515-27$.}

\section{TRUMP AND THE TRANSATLANTIC RELATIONSHIP IN CRITICAL PERSPECTIVE}

Lora Anne Viola, Freie Universität Berlin, Germany

\section{DOI: $10.1017 / S_{1049096519001951}$}

When the newly appointed US Ambassador to Germany, Richard Grenell, arrived in Berlin, he immediately caused a media firestorm. Ambassador Grenell flaunted diplomatic protocol by making a series of statements that appeared to undermine the current German government, support right-wing political parties, and criticize the "blatant anti-Americanism" in German media. ${ }^{1}$ Former German ambassador to the United States, Wolfgang Ischinger, retorted via Twitter: "Never tell the host country what to do, if you want to stay out of trouble."2 In Germany, Grenell's contentious diplomacy has become emblematic of the deterioration of US-German relations since the election of President Trump. Trump has regularly taken Germany to task for its trade policies and defense spending, even threatening to take punitive action including tariff increases and withdrawal from NATO. In turn, Germany, more than any other major ally, sees its relations with the United States as having severely worsened since Trump's election, and Germans currently view the United States more negatively than at any other point since the end of the Cold War. ${ }^{3}$

This state of affairs has generated an intense demand on the part of politicians, students, and the general public to better understand American politics, both domestic and international. US politics is followed almost as intensively as domestic politics. Both the media and policy makers frequently reach out to 
US foreign-policy experts to give interviews, provide background information, and consult on policy debates. At American studies programs, such as the John F. Kennedy Institute at the Freie Universität Berlin, student enrollment numbers have been increasing steadily, and the percentage of students interested in studying US politics in particular is very high. In meeting this demand, one discussions about the future of German foreign policy. The discussions include the controversial issue of increasing German defense spending and its willingness to use force; thinking critically about NATO and the European Union's dependence on the US security umbrella; and reconsidering the leadership role that Germany could and should play in managing international

\section{Germany, more than any other major ally, sees its relations with the United States as having severely worsened since Trump's election, and Germans currently view the United States more negatively than at any other point since the end of the Cold War.}

of the central challenges is to tame the instinct to explain current US foreign policy in terms of a sui generis presidency driven by the idiosyncratic qualities of President Trump. There has been significant wishful thinking in German political discourse that Trump's presidency is an anomaly that sooner or later will disappear, allowing politics to return to normal.

The tendency to see Trump as exceptional, along with his deep unpopularity in Germany, results in three distinct teaching challenges. First, it is an analytical challenge to disentangle the person of the president from other relevant factors influencing the administration's foreign policy. In the classroom, it has been useful to return to the three levels of analysis as a heuristic device to think about the relative roles of individuals, domestic institutions, and systemic-level factors in shaping US foreign policy. On the one hand, this presidency seems to require an explanatory framework that considers psychology, which presents an opportunity to teach about individual-level explanations that are receiving renewed scholarly attention in the field. This is especially relevant in contemporary Germany, where a leader's personality traditionally has been less important to the political debate but where the personalization of politics appears to be on the rise. On the other hand, it is important not to lose sight of domestic variables, including demographic change, economic inequality, and electoral incentives, as well as international geopolitical conditions, such as hegemonic rivalry, that continue to shape US foreign policy. Debating the relative weight of individual-, domestic-, and systemic-level factors makes for lively classroom debate but also provides some critical distance from the instinct to focus on the sensationalism surrounding Trump's character and personality.

The second teaching challenge is to move beyond current events by putting this presidency and its foreign policy in the context of historical change. Trump's foreign policy has caused many observers to anxiously argue that the transatlantic relationship is in fundamental crisis. In reality, the transatlantic relationship has been undergoing a slow transformation since the end of the Cold War. US strategic interests have been shifting away from Europe, naturally weakening the US commitment to the region. Meanwhile, Germany's strong economy has made it a dominant player within Europe, accompanied by growing political influence. As Germany slowly accepts the mantel of power, its interests are diversifying and its foreign policy is becoming more independent of the United States. Trump's presidency has only made these changes more apparent. Thus, teaching US foreign policy now in Germany demands engaging in difficult order on topics ranging from the rise of China to nuclear nonproliferation and climate change.

The third teaching challenge, particularly relevant in Europe, is to put the Trump presidency and its foreign policy in comparative perspective. The tendency to see Trump as an American anomaly easily distracts attention from asking about the connections between his politics and the current political context of Germany and Europe more broadly. Germans tend to see Trump as something perplexing happening "over there" but, in fact, there are many parallels to political trends in Germany and Europe. In the classroom, this presents an important opportunity to think critically about Trump's foreign policy in light of the rise of nationalist populism in Europe, right-wing hostility to immigrants and refugees, and the broader shift toward authoritarian democracy. How are these trends on the two sides of the Atlantic related? Do they share underlying causes and similar consequences? Do they reinforce one another or does their coexistence open a certain policy space as permissible? Studying US politics, in other words, should not be a distraction from local political engagement but rather should provide students with an impetus to reconsider and to mobilize around European political challenges. This is especially important because all three of the teaching challenges indicate a broader lesson: that global politics will not simply return to the status quo post-Trump and that the changes underway are not driven by one person-or even one country-alone.

From an instructor's viewpoint, teaching US foreign policy in Europe to an international student body-including students from countries with vastly different experiences of US global leadership-affords a fresh perspective on current politics. Students outside of the United States are highly attuned to the normative narrative of American greatness that underpins not only the practice but often also the study of US foreign policy. Studying the United States from outside of the country thus opens up a critical distance that facilitates the interrogation of assumptions and arguments-and that is a characteristic of good social science everywhere.

\footnotetext{
NOTES

1. See, for example, https://twitter.com/RichardGrenell/status/993924107212394496; www.breitbart.com/europe/2018/o6/o3/trumps-right-hand-man-in-europewants-to-empower-european-anti-establishment-conservatives; www.spiegel.de/ international/world/u-s-ambassador-richard-grenell-is-isolated-in-berlina-1247610.html; and www.spiegel.de/media/media-43953.pdf.

2. Available at https://twitter.com/ischinger/status/99411351860463616o.

3. Available at www.pewglobal.org/2018/10/o1/trumps-international-ratings-remainlow-especially-among-key-allies.
} 